Original Research Article

\title{
Antibiotic use: evaluating knowledge, attitude and practices among medical students in a sub Himalayan state
}

\author{
Rajiv Kumar Gupta ${ }^{1 *}$, Parveen Singh ${ }^{1}$, Renu Rani ${ }^{2}$, Rashmi Kumari ${ }^{1}$, \\ Bhavna Langer ${ }^{1}$, Riya Gupta ${ }^{3}$
}

${ }^{1}$ Department of Community Medicine, Government Medical College, Jammu, J\&K, India ${ }^{2}$ Directorate of Health Services, Jammu, J\&K, India ${ }^{3}$ Department of Community Medicine, Acharya Shri Chander College of Medical Sciences and Hospital, Sidhra, Jammu, J\&K, India

Received: 11 August 2017 Accepted: 04 September 2017

\section{*Correspondence to: \\ Dr. Rajiv Kumar Gupta, Email: rajivguptagmc@ rediffmail.com}

Copyright: () the author(s), publisher and licensee Medip Academy. This is an openaccess article distributed under the terms of the Creative Commons Attribution NonCommercial License, which permits unrestricted noncommercial use, distribution, and reproduction in any medium, provided the original work is properly cited.

\begin{abstract}
Background: The growing concern about antibiotic resistance, of late, led World Health Organization to declare it as World Health Day theme in 2011. Knowledge spreads awareness and understanding by melting the barriers of ignorance while attitudes and practices have a bearing on the health related behaviour. The present study aims at evaluating the knowledge, attitudes and practices of medical students towards antibiotic usage.

Methods: The present cross-sectional study was conducted among the Pre-final medical students $\left(6^{\text {th }} / 7^{\text {th }}\right.$ semester $)$ who participated in the questionnaire survey on knowledge, attitude and practice towards antibiotics usage. The data was analysed and Chi-square was used as test of significance.

Results: Overall, 132 students were interviewed. Majority (96.2\%) had heard of antibiotic resistance. About $22 \%$ of the sample stated that antibiotics can cure viral infections, among them female being in the higher proportion $(p<0.05)$. Majority (>90\%) agreed that antibiotic resistance is a serious problem and had positive attitude about population awareness campaign regarding antibiotic resistance. Among practices, higher proportion of male respondents preferred antibiotics in case of cough and sore throat. $(\mathrm{p}<0.05)$.

Conclusions: Despite being Pre-final MBBS students, the results have revealed that knowledge and attitude of the respondents were not up to the desired levels. The practices regarding use of antibiotics were more or less adequate. For effective curriculum, thorough knowledge and rational prescription of antibiotics needs to be reinforced among medical students both before and during internship.
\end{abstract}

Keywords: Antibiotic use, KAP, Medical students

\section{INTRODUCTION}

With the advent of penicillin, it was assumed that we have entered into the golden era of clinical practice as the penicillin and discovery of other antibiotics were hailed as magic bullets. But it was evident rather soon that resistance to the antibiotics was developing rather too quickly thus terminating the so called magic. The gravity of the problem has progressed over the years and antibiotic resistance has become a worldwide public health concern.
The alarming situation led WHO to set the theme of World Health Day in 2011 as 'Combat Antimicrobial Resistance: No Action Today, No Cure Tomorrow'. ${ }^{1}$

Although antibiotics are the most frequently prescribed drugs, yet these are often misused. ${ }^{2,3}$ The misuse, in turn, has contributed to the spread of resistance strains of bacteria. ${ }^{4}$ Among the various causes of antimicrobial misuse, one is the wrong prescribing behaviour among the physicians. ${ }^{5-7}$ Many factors could influence the behaviour 
of prescribing physicians e.g. consideration of future complications to the patients, desire to full fill the expectation of the treating patients etc. ${ }^{8,9}$ Among the other causes, wrong habits of the patients and lack of knowledge on their part has also contributed to growing antimicrobial resistance. ${ }^{8,10}$

India has a high burden of infectious diseases which has led to wide and frequent use of antibiotics thus accounting for the alarming increase in antimicrobial resistance in the country. ${ }^{11}$ Besides unchecked over the counter (OTC) sale, availability of antibiotics for human, animal as well as industrial consumption have all added to the problem in our country. On the part of public; self medication, lack of knowledge, unjustified demand for antibiotic prescription and unawareness regarding antibiotic resistance are other reason for the emerging scenario of anti-microbial resistance in India.

To combat this problem, India established a national surveillance data base for antibiotic use and National Centre for Disease Control (NCDC) was designated as the focal point for anti microbial resistance in the country. ${ }^{12}$ Besides this, it is pertinent to mention that specific measures need to be directed at the individual level which in turn has a bearing on the health related behaviour.

In this context, medical students represent an educated group who are the future health care providers of the nation. Antibiotic use and resistance are taught to them in pharmacology and microbiology while practice of antibiotics prescription is supervised by clinicians during their clinical internship. During review of literature, KAP (Knowledge, attitude and practices) studies were found to be conducted among $2^{\text {nd }}$ professional MBBS students in various places in India. The authors aimed to assess the KAP of Pre-final MBBS students ( $6^{\text {th }}$ and $7^{\text {th }}$ semester) who have cleared $2^{\text {nd }}$ professional which usually pertains to the domain of antibiotic use as well as resistance.

\section{METHODS}

The present cross-sectional questionnaire based study was conducted by the department of Community Medicine, Government Medical College Jammu in the month of April 2017.

The study was carried out amongst a convenience sample of the Pre-final MBBS students who had already received briefing on antibiotics in pharmacology and microbiology. The aim was to assess the KAP of the Pre-final students about antimicrobial use after they had been adequately taught about these components in detail in the previous profession. The participation was voluntary and without any compensation. The students were ensured that anonymity would be maintained and ethical principles would be followed. Before the administration of questionnaire, the objectives and intentions of the survey were explained and students were encouraged to participate without any undue pressure. Informed verbal consent was obtained from all the participants.

The questionnaire for the current study was developed by faculty of Community Medicine in consultation with experts from Pharmacology department. The questionnaire was validated by a pilot on 25 medical students who eventually didn't from the study population.

The final version of the questionnaire had questions subdivided into four parts: the first part was sociodemographic characteristics of the students interviewed, the second part was addressed to assess the knowledge about antibiotics, the third part elicited attitude of the respondents towards antimicrobials and fourth part was about usage and practices adopted by them about antibiotics.

Data was collected, tabulated and analysed. Pearson's Chi square test was used to assess the association between KAP towards antibiotics and gender of medical students. A value of $\mathrm{p}<0.05$ was considered statistically significant.

\section{RESULTS}

The questionnaire was administered to132 Pre-final MBBS students who were present in the class on the day the current study was carried out. $55.30 \%$ of the respondents were females, $51.52 \%$ of them belonged to Hindu religion while $39.39 \%$ were of Muslim religion. About two third $(62.88 \%)$ of them belonged to the urban areas and about half (48.48\%) of household heads had literacy levels up to graduation level (Table 1).

Table 1: Socio-demographic profile of the respondents $(n=132)$.

\begin{tabular}{|ll|}
\hline Socio-demographic variable & Frequency (\%) \\
\hline Sex & \\
\hline Male & $59(44.69)$ \\
\hline Female & $73(55.30)$ \\
\hline Religion & $68(51.52)$ \\
\hline Hindu & $52(39.39)$ \\
\hline Muslim & $07(5.30)$ \\
\hline Sikh & $05(3.79)$ \\
\hline Others & \\
\hline Residence & $49(37.12)$ \\
\hline Rural & $83(62.88)$ \\
\hline Urban & \\
\hline Literacy status of head of the family & $07(5.30)$ \\
\hline Illiterate & $37(28.03)$ \\
\hline Up to matric & $64(48.48)$ \\
\hline Up to graduation & $24(18.18)$ \\
\hline Post graduation &
\end{tabular}

$96.21 \%$ of the respondents had heard of antibiotic resistance and $93.94 \%$ replied yes to the meaning of antibiotic resistance. Higher proportion of male 
respondents were aware of antibiotics not curing viral infections $(\mathrm{p}<0.05)$. Almost equal proportion of male and female respondents were aware of antibiotics causing allergic reactions $(p>0.05) .32 .20 \%$ of the male respondents replied positive for better efficacy of antibiotics if they are of recent origin and more costly in comparison to $16.44 \%$ of female respondents $(p<0.05)$. Higher proportion of female respondents replied in positive for adverse effects of antibiotics being reduced by using more than one antimicrobial at a time $(\mathrm{p}<0.05)$. More than $80 \%$ of the respondents were aware that indiscriminate and injudicious use of antibiotics can lead to ineffective treatment, increased adverse effects, prolongation of illness and additional burden of cost to the patient ( $>0.05)$ (Table 2).

Table 2: Awareness of respondents regarding antibiotic usage ( $n=132)$.

\begin{tabular}{|c|c|c|c|c|c|}
\hline Question & Response & $\begin{array}{l}\text { Male } \\
(n=59)\end{array}$ & $\begin{array}{l}\text { Female } \\
(n=73)\end{array}$ & $\begin{array}{l}\text { Total } \\
(n=132)\end{array}$ & P value \\
\hline \multirow{2}{*}{ Have you heard of antibiotics resistance } & Yes & $56(94.92)$ & $71(97.26)$ & $127(96.21)$ & \multirow{2}{*}{0.79} \\
\hline & No & $03(5.08)$ & $02(2.74)$ & $05(3.79)$ & \\
\hline \multirow{2}{*}{$\begin{array}{l}\text { Antimicrobial resistance means that if they are taken } \\
\text { too often, antimicrobials are less likely to work in the } \\
\text { future }\end{array}$} & Yes & $54(91.52)$ & $70(95.89)$ & 124(93.94) & \multirow[b]{2}{*}{0.49} \\
\hline & No & $05(8.47)$ & $03(4.11)$ & $08(6.06)$ & \\
\hline \multirow{2}{*}{ Can antibiotic cure viral infections } & Yes & $06(10.17)$ & $23(31.51)$ & $29(21.97)$ & \multirow{2}{*}{0.00} \\
\hline & No & $53(89.83)$ & $50(68.49)$ & $103(78.03)$ & \\
\hline \multirow{2}{*}{ Can antibiotics cause allergic reactions } & Yes & $53(89.83)$ & $68(93.15)$ & 121(91.67) & \multirow{2}{*}{0.49} \\
\hline & No & $06(10.17)$ & $05(6.85)$ & $11(8.33)$ & \\
\hline \multirow{2}{*}{$\begin{array}{l}\text { Is the efficacy better if the antibiotics are of recent } \\
\text { origin and costlier }\end{array}$} & Yes & $19(32.20)$ & $12(16.44)$ & $31(23.48)$ & \multirow{2}{*}{0.03} \\
\hline & No & $40(67.79)$ & $61(83.56)$ & $101(76.51)$ & \\
\hline \multirow{2}{*}{$\begin{array}{l}\text { Adverse effects of antimicrobials are reduced by } \\
\text { using more than one antimicrobial at a time }\end{array}$} & Yes & $30(50.85)$ & $51(69.86)$ & $81(61.36)$ & \multirow{2}{*}{0.02} \\
\hline & No & $29(49.15)$ & $22(30.14)$ & $51(38.64)$ & \\
\hline $\begin{array}{l}\text { Indiscriminate and Injudicious use of antibiotics can } \\
\text { lead to }\end{array}$ & Yes & $55(93.22)$ & $69(94.52)$ & $124(93.94)$ & \multirow[t]{2}{*}{0.74} \\
\hline Ineffective treatment & No & $04(6.78)$ & $04(5.48)$ & $08(6.06)$ & \\
\hline \multirow{2}{*}{ Increased adverse effects } & Yes & $57(96.61)$ & $70(95.89)$ & $127(96.21)$ & \multirow{2}{*}{0.82} \\
\hline & No & $02(3.39)$ & $03(4.11)$ & $05(3.79)$ & \\
\hline \multirow{2}{*}{ Exacerbation or Prolongation of illness } & Yes & $50(84.75)$ & $59(80.82)$ & $109(82.58)$ & \multirow{2}{*}{0.55} \\
\hline & No & $09(15.25)$ & $14(19.18)$ & $23(17.42)$ & \\
\hline \multirow{2}{*}{ Additional burden of medical cost to the patient } & Yes & $54(91.53)$ & $65(89.04)$ & $119(90.15)$ & \multirow{2}{*}{0.63} \\
\hline & No & $05(8.47)$ & $08(10.96)$ & $13(9.85)$ & \\
\hline
\end{tabular}

Table 3: Attitude of respondents regarding antibiotic resistance $(n=132)$.

\begin{tabular}{|c|c|c|c|c|c|}
\hline Question & Response & $\begin{array}{l}\text { Male } \\
(\mathrm{n}=59)\end{array}$ & $\begin{array}{l}\text { Female } \\
(\mathrm{n}=73)\end{array}$ & $\begin{array}{l}\text { Total } \\
(\mathbf{n}=132)\end{array}$ & $\begin{array}{l}\mathbf{P} \\
\text { value }\end{array}$ \\
\hline \multirow{2}{*}{$\begin{array}{l}\text { Antibiotic Resistance is } \\
\text { a) An important and serious public issue facing the world }\end{array}$} & Yes & $57(96.61)$ & $70(95.89)$ & 127(96.21) & \multirow{2}{*}{0.82} \\
\hline & No & $02(3.39)$ & $03(4.11)$ & $05(3.79)$ & \\
\hline \multirow{2}{*}{ b) An important and serious public health issue in India } & Yes & $55(93.22)$ & $69(94.52)$ & 124(93.94) & \multirow{2}{*}{0.75} \\
\hline & No & $04(6.78)$ & $04(5.48)$ & $08(6.06)$ & \\
\hline \multirow{2}{*}{$\begin{array}{l}\text { When I have a cold/fever, I should take antibiotics to } \\
\text { prevent getting a more serious illness }\end{array}$} & Yes & $18(30.51)$ & $36(49.31)$ & $54(40.91)$ & \multirow{2}{*}{0.02} \\
\hline & No & $41(69.49)$ & $37(50.68)$ & $78(59.09)$ & \\
\hline \multirow{2}{*}{$\begin{array}{l}\text { Skipping one or two doses does not contribute to the } \\
\text { development of antibiotic resistance }\end{array}$} & Yes & $28(47.46)$ & $22(30.14)$ & $50(37.88)$ & \multirow{2}{*}{0.04} \\
\hline & No & $31(52.54)$ & $51(69.86)$ & $82(62.12)$ & \\
\hline \multirow{2}{*}{$\begin{array}{l}\text { Antibiotics are safe drugs; hence they can be commonly } \\
\text { used. }\end{array}$} & Yes & $8(13.56)$ & $24(32.88)$ & $32(24.24)$ & \multirow{2}{*}{0.01} \\
\hline & No & $51(86.44)$ & $49(67.12)$ & $100(75.76)$ & \\
\hline \multirow{2}{*}{$\begin{array}{l}\text { Is it necessary to carry out large scale antibiotics } \\
\text { campaign promotion to create awareness among the } \\
\text { population and health care professional }\end{array}$} & Yes & $56(94.92)$ & $67(91.78)$ & 123(93.18) & \multirow{2}{*}{0.47} \\
\hline & No & $03(5.08)$ & $06(8.22)$ & $09(6.82)$ & \\
\hline \multirow{2}{*}{$\begin{array}{l}\text { Do you share information about antimicrobial resistance } \\
\text { with parents/ friends }\end{array}$} & Yes & $54(91.53)$ & 70(95.89) & 124(93.94) & \multirow{2}{*}{0.29} \\
\hline & No & $05(8.47)$ & $03(4.11)$ & $08(6.06)$ & \\
\hline
\end{tabular}


Table 4: Practice of respondents regarding use of antibiotics $(n=132)$.

\begin{tabular}{|c|c|c|c|c|c|}
\hline Question & Response & $\begin{array}{l}\text { Male } \\
(n=59)\end{array}$ & $\begin{array}{l}\text { Female } \\
(n=73)\end{array}$ & $\begin{array}{l}\text { Total } \\
(\mathrm{n}=132)\end{array}$ & $\begin{array}{l}P \\
\text { value }\end{array}$ \\
\hline \multicolumn{6}{|c|}{ The doctor prescribes a course of antibiotic for you. After taking 2-3 doses you start feeling better } \\
\hline \multirow{2}{*}{ a) Do you stop taking the further treatment } & Yes & $09(15.25)$ & 14(19.18) & 23(17.42) & \multirow{2}{*}{0.55} \\
\hline & No & $50(84.75)$ & $59(80.82)$ & $109(82.58)$ & \\
\hline \multirow{2}{*}{ b) Do you discard the remaining, leftover medication } & Yes & $15(25.42)$ & $08(10.96)$ & $23(17.42)$ & \multirow{2}{*}{0.02} \\
\hline & No & 44(74.58) & 65(89.04) & $109(82.58)$ & \\
\hline \multirow{2}{*}{$\begin{array}{l}\text { c) Do you give the leftover antibiotics to your } \\
\text { friend/roommate if they get sick }\end{array}$} & Yes & $32(54.23)$ & $22(30.14)$ & $54(40.91)$ & \multirow{2}{*}{0.00} \\
\hline & No & $27(45.76)$ & $51(69.86)$ & 78(59.09) & \\
\hline \multirow{2}{*}{ Do you consult a doctor before starting the treatment } & Yes & $50(84.75)$ & $59(80.82)$ & $109(82.58)$ & \multirow{2}{*}{0.55} \\
\hline & No & $09(15.25)$ & 14(19.18) & $23(17.42)$ & \\
\hline \multirow{2}{*}{$\begin{array}{l}\text { Do you check the expiry date of the antibiotic before } \\
\text { using it }\end{array}$} & Yes & $55(93.22)$ & 71(97.26) & $126(95.45)$ & \multirow{2}{*}{0.49} \\
\hline & No & $04(6.78)$ & $02(2.74)$ & $6(4.55)$ & \\
\hline \multirow{2}{*}{$\begin{array}{l}\text { Do you prefer to take an antibiotic when you have } \\
\text { cough and sore throat }\end{array}$} & Yes & $45(76.27)$ & $40(54.79)$ & $85(64.39)$ & \multirow{2}{*}{0.01} \\
\hline & No & 14(23.73) & $33(45.21)$ & $47(35.61)$ & \\
\hline \multirow[t]{2}{*}{ Do you buy antibiotics without medical prescription } & Yes & $34(57.63)$ & 41(56.16) & $75(56.82)$ & \multirow[t]{2}{*}{0.86} \\
\hline & No & 25(42.37) & $32(43.84)$ & $57(43.18)$ & \\
\hline
\end{tabular}

Majority of the respondents (>90\%) agreed that antibiotic resistance is a serious problem across the world as well in India. Higher proportion of male respondents replied in negative about antibiotic use in case of cold/fever than their female counterparts and this difference was found to be statistically significant $(\mathrm{p}<0.05)$. Female respondents had better attitude about skipping of one or two doses of antibiotics causing antibiotic resistance than male respondents $(\mathrm{p}<0.05)$. On the other hand, results revealed that higher proportion of male respondents were aware about antibiotics are not be used commonly $(\mathrm{p}<0.05)$. Majority of the respondents $(>90 \%)$ had positive attitude about population awareness campaigning regarding antibiotic resistance and sharing information about antibiotic resistance with parents /friends (Table 3).

Regarding practices, it was found that $82.5 \%$ respondents didn't stop the treatment even after feeling better after intake of 2-3 doses of antibiotics while equal proportion don't discard the left over medication after taking the prescribed course. On the basis of sex, male respondents reported higher discard rate than their female counterparts $(p<0.05)$. Similarly higher proportion of male respondents practised giving left over antibiotics to a friend/ roommate if they get sick $(p<0.05)$. Majority $(>80 \%)$ of them consulted a doctor before starting an antibiotic and also checked expiry date before using the antibiotic. Higher proportion of male respondents preferred to use antibiotic in case of cough and sore throat and this difference was found to be statistically significant $(\mathrm{p}<0.05)$ (Table 4$)$.

\section{DISCUSSION}

The present study evaluated knowledge, attitude and practices of pre-final $\left(6^{\text {th }}\right.$ and $7^{\text {th }}$ semester) medical undergraduates. $96 \%$ of the respondents had heard of antibiotic resistance and $94 \%$ were aware of the meaning of antibiotic resistance. Similar results were reported by Mahajan $\mathrm{M}$ et al, in Central India. ${ }^{13}$ An Italian study reported this rate to be $93.9 \% .{ }^{14}$ On the other hand, Sharma $\mathrm{S}$ et al, in their study reported that all the participants had heard of antibiotic resistance. ${ }^{15}$ Awareness of respondents was found poor when $22 \%$ of them reported that antibiotics can cure viral infections, $23.48 \%$ felt that newer and costly drugs have better efficacy and about $61 \%$ replied that adverse effects of antibiotics can be reduced by using more than one antimicrobial at a time. These findings are more or less in agreement with results reported by Sharma $\mathrm{S}$ et al, in their study conducted in Kerala. ${ }^{15}$ Scaioli $\mathrm{G}$ et al, reported almost similar results when $20 \%$ of respondents said that antibiotics are appropriate for viral infections. ${ }^{14}$ Such mediocre levels of knowledge about antibiotics is a cause of concern as the study sample has already cleared the $2^{\text {nd }}$ professional examination and authors expected a much better knowledge from this cohort. Other parameters of knowledge like antibiotic causing allergic reaction and indiscriminate use of antibiotic leading to ineffective treatment, increased adverse effects, prolongation of illness etc were found to be adequate. Scaioli $\mathrm{G}$ et al, in their study in Italy also reported that $93.4 \%$ of the respondents had knowledge about antibiotics causing allergic reactions. ${ }^{14}$

Majority of the respondents opined that antibiotics resistance is a serious problem facing the world in general and India in particular which was also reported by Sharma $\mathrm{S}$ et al, and other previous studies conducted among medical students. ${ }^{13,15-19}$ Only three quarters of the respondents rated antibiotics unsafe and opined that they should not be used as routine. Surprisingly higher proportion of female students rated antibiotics as safe than their male counterparts $(\mathrm{p}<0.05)$ and this attitudes among Pre-final MBBS students is not a good sign. Higher proportion of respondents $(55 \%)$ reported antibiotics to be 
safe drugs in the study conducted by Sharma $\mathrm{S}$ et al, in Kerala. ${ }^{15}$ Although antibiotics are generally safe but every drug can cause adverse drug reaction which may vary from person to person. Among the positive attitude, majority agreed for the need of campaign to create awareness among the population as well as health care professional. To combat growing problem of antibiotic resistance, spreading awareness was also reported by Mahajan $\mathrm{M}$ et al, and Sharma S et al. ${ }^{13,15}$

Despite lackasidical attitude among the respondents, the self reported practices with regard to use of antibiotics were found to be reasonably appreciable. About $83 \%$ don't stop treatment even after improvement with initial 2-3 doses, $82.5 \%$ didn't discard the left over medications and $40 \%$ replied that they would provide antibiotics to a friend if need arises. These results are in congruence with those reported by Mahajan $\mathrm{M}$ et al, Sharma $\mathrm{S}$ et al, Khan AK et al, and Taro SM et al. ${ }^{13,15,17,19}$ Majority in current study consulted a doctor before starting the treatment and were in habit of checking expiry dates of antibiotics which is in agreement with the results reported by Mahajan $\mathrm{M}$ et al, Scaioli G et al, and Khan AK et al. ${ }^{13,14,17}$

In view of the results of the current study, the strategy of medical education should be not only to increase the knowledge but also to change the behaviour as well as practices among the medical students. The principles of protocol development for antibiotic use in health care facilities should be an integral part of undergraduates teaching. Results have revealed that learning about antibiotic use in pharmacology left a lot to be desired. Simple measures like hand hygiene for control of resistance need to be inoculated in day to day life.

\section{Limitations}

The convenience sampling method involving only a single batch of students is a major limitation of the current study. Another limitation is a self administered questionnaire which could lead to recall bias caused by differences in the accuracy by recollections retrieved by respondents resulting in under reporting or over reporting.

\section{CONCLUSION}

The current study has demonstrated how the medical students lack the level of knowledge about antibiotics despite having studied the relevant disciplines earlier. Even some of the attitudes on the part of the respondents were still incorrect, though practices regarding use of antibiotics were found to be reasonably adequate. Since the medical students are likely to be a role model for both the general public as well as patients once they become doctors, it is imperative to impart them a thorough knowledge on this topic during their degree courses. It would be prudent to add that rational prescription of antibiotics courses be held that emphasises more on behaviour of medical students towards antibiotics usage along with advancing of knowledge.
Funding: No funding sources

Conflict of interest: None declared

Ethical approval: The study was approved by the Institutional Ethics Committee

\section{REFERENCES}

1. World Health Day 2011-Antibiotic resistance: No action today, no cure tomorrow. Available at: http://www.who.int/mediacentre/news/statements/20 11/whd_20110407/en/index.html. Last accessed 19 July 2107

2. Chambers HF. General principles of antimicrobial therapy. In Goodman \& Gilman's The Pharmacological Basis of Therapeutics $11^{\text {th }}$ Edition. Editors: Brunton L, Parker K, Blumenthal D, Buxton I. New York, USA, Mc Graw Hill; 2006:1095-1110.

3. World Health Organization (WHO). Antimicrobial Resistance. Global Report on Surveillance. Geneva: World Health Organization, 2014. Available at: http://apps.who.int/iris/bitstream/10665/112642/1/97 89241564748_eng.pdf. Last accessed 23 July 2017.

4. Centers for Disease Control and Prevention (CDC). Antibiotics Aren't Always the Answer. 2013. Available at: http://www.cdc.gov/Features/GetSmart/. Last accessed: 5 August 2017.

5. Tonkin-Crine S, Yardley L, Little P. Antibiotic prescribing for acute respiratory tract infections in primarycare: a systematic review and metaethnography. J Antimicrob Chemother. 2011;66(10):2215-23.

6. Butler CC, Rollnick S, Pill R, Maggs-Rapport F, Stott $\mathrm{N}$. Understanding the culture of prescribing: qualitative study of general practitioners' and patients' perceptions of antibiotics for sore throats. BMJ. 1998;317(7159):637-42.

7. Kumar S, Little P, Britten N. Why do general practitioners prescribe antibiotics for sore throat? Grounded theory interview study. BMJ. 2003;326(7381):138.

8. World Health Organization (WHO). The evolving threat of antimicrobial resistance. Options for action. Geneva: World Health Organization, 2012. Available at: http://whqlibdoc.who.int/publications/2012/9789241 503181_eng.pdf. Last accessed 5 August 2017.

9. Teixeira Rodrigues A, Roque F, Falcão A, Figueiras A, Herdeiro MT. Understanding physician antibiotic prescribing behaviour: a systematic review of qualitative studies. Int $\mathrm{J}$ Antimicrob Agents. 2013;41(3):203-12.

10. Cars O, Mölstad S, Melander A. Variation in antibiotic use in the European Union. Lancet. 2001;357(9271):1851-3.

11. World health organization. Prevention and containment of antimicrobial resistance. Available at: http://www.ino.searo.who.int/LinkFiles/Other_Conte nt_WHD11-Seminar_Presentation-WRpdf. Last accessed 5 August 2017. 
12. Directorate general of health service. National policy for containment of antimicrobial resistance India. Available at: http://nicd.nic.in/ab_policy.pdf. Last accessed 5 August 2017.

13. Mahajan M, Dughgaonkar S, Deshmukh S. A questionnaire based survey on the knowledge, attitude and practises about antimicrobial resistance and usage among the second year MBBS students of a teaching tertiary care hospital in central India. International Journal of Pharmacological Research. 2014;4:175-9.

14. Scaioli G, Gualano MR, Gill R, Masucci S, Bert F, Siliquini R. Antibiotic use: A cross sectional assessing the knowledge, attitudes and practices amongst students of a school of medicine in Italy. PLoS ONE. 2015;10:0122-476.

15. Sharma S, Jayakumar D, Palappallil DS, Kesavan KP. Knowledge, attitude and practices of antibiotic usage and resistance among the second year MBBS Students. Int J Basic Clin Pharmacol. 2016;5:899-903.

16. Abbo LM, Cosgrove SE, Pottinger PS, Pereyra M, Sinkowitz-Cochran R, Srinivasan A. Medical student ${ }^{\text {ee }}$ perceptions and knowledge about antimicrobial stewardship: how are we educating our future prescribers? Clin Infect Dis. 2013;57:631-8.
17. Khan AK, Banu G, KK R. Antibiotic resistance and usage-a survey on the knowledge, attitude, perceptions and practices among the medical students of a Southern Indian teaching hospital. J Clin Diagn Res. 2013;7:1613-6.

18. Huang Y, Gu J, Zhang M, Ren Z, Yang W, Chen Y, et al. Knowledge, attitude and practice of antibiotics: a questionnaire study among 2500 Chinese students. BMC Medical Education. 2013;13:163.

19. Tarao SM, Nulla P, Zingpi M, Agatha G. A study on the knowledge, attitude, perceptions and practices of antibiotic usage and resistance among the medical students of JNIMS, Imphal, Manipur. Journal of Evidence Based Medicine and Healthcare. 2015;2:5262-8.

Cite this article as: Gupta RK, Singh P, Rani R, Kumari R, Langer B, Gupta R. Antibiotic use: evaluating knowledge, attitude and practices among medical students in a sub Himalayan state. Int $\mathbf{J}$ Basic Clin Pharmacol 2017;6:2516-21. 